\title{
Trace elements in bivalve shells from the Río Cruces, Chile
}

\author{
Michael J. Risk ${ }^{1, *}$, Meghan Burchell ${ }^{2}$, Katharina de Roo $^{3}$, Rob Nairn ${ }^{3}$, Mike Tubrett ${ }^{4}$, \\ Gunter Forsterra $^{5}$
}

\author{
${ }^{1}$ School of Earth Sciences, McMaster University, Hamilton, Ontario, Canada \\ ${ }^{2}$ Department of Anthropology, McMaster University, Hamilton, Ontario, Canada \\ ${ }^{3}$ Baird \& Associates, Oakville, Ontario, Canada \\ ${ }^{4}$ Inco Innovation Centre, Memorial University of Newfoundland, St. John's, Newfoundland, Canada \\ ${ }^{5}$ Pontificia Universidad Católica de Valparaíso, Valparaíso, Chile
}

\begin{abstract}
In May 1960, the largest recorded earthquake in the earth's history struck southern Chile, and lowered the course of the Río Cruces by approximately $2 \mathrm{~m}$. This created a wetland, which was colonised by the waterweed Egeria densa and, subsequently, by large populations of the blacknecked swan, which fed on the weed. Reported catastrophic declines in the weed and swan populations in 2004 coincided with the opening of a large cellulose plant upstream, leading to popular and scientific condemnation of the plant. In 2008, samples of the freshwater bivalve Diplodon chilensis were retrieved from the bed of the Río Cruces at several locations downstream of the plant, and the growth patterns of the bivalves were studied in thin section. Trace element profiles of bivalves were determined by laser ablation inductively coupled plasma mass spectrometry (LA-ICP/MS). Some of the bivalves had ages of almost $50 \mathrm{yr}$, indicating that they colonised the drowned riverbed less than a decade after the earthquake. There were no growth recessions or abnormalities in the shells corresponding to 2004, the year the plant opened. Patterns of trace elements in the shells describe aspects of the evolution of the watershed, track annual cycles in rainfall and indicate patterns of soil erosion and/or sediment input. Sr, Ba and Mn have strong annual cyclicity; Ba and Mn are viewed as indicators of soil erosion. Peaks in Ba were large immediately after the earthquake, whereas Ba peaks in the last few decades were of much smaller amplitude. The changes in Ba patterns probably indicate changes in patterns of soil erosion: high erosion rates immediately after the earthquake, slowing as the basin fills. $\mathrm{Cu}$ appears as annual low-level peaks in abundance in about 1975, which continue to the present. This may be the result of spraying of fungicides in the watershed, which is heavily used by agriculture. Similarly, scattered peaks in As around 1980 may indicate the use of pesticides. There is no evidence in the bivalve shells of a chemical spill in 2004.
\end{abstract}

KEY WORDS: Egeria densa $\cdot$ Black-necked swans $\cdot \delta^{18} \mathrm{O} \cdot$ Bivalves $\cdot$ Diplodon chilensis $\cdot$ Trace elements $\cdot$ CELCO Plant

Resale or republication not permitted without written consent of the publisher

\section{INTRODUCTION}

On 21-22 May 1960, Chile was struck by the largest earthquake ever recorded, magnitude 9.5. This earthquake resulted from a rupture nearly $1000 \mathrm{~km}$ long on a north-south trending fault that carries the Nazca Plate under the South American Plate, at rates averaging 8 m per century (Plafker \& Savage 1970).
The earthquake dropped the course of the Río Cruces approximately $2 \mathrm{~m}$, from a point near Fuerte San Martín down to the Pacific coast. This created a wetland zone (subsequently classified as a RAMSAR sanctuary) composed of slow-moving streams, swamps and a tidal estuary that empties into the Pacific Ocean (Fig. 1). After the earthquake, the wetland was colonized by the Brazilian waterweed Egeria densa (known locally as 
luchecillo), an introduced species which is a pest elsewhere in the world. This weed became the principal food of the black-necked swan Cygnus melanocorypha, and populations of the swan began to increase.

In 2004 and 2005, simultaneous declines were reported in the abundance of luchecillo and the swans. The population of black-necked swans reportedly fell from approximately 5000 in 2003 to around 220 individuals as of April 2005; Universidad Austral de Chile (UAC 2005) reported that direct mortality was first observed in September 2004 and that 99 dead swans were counted in 2004, and it is believed the rest of the swans migrated to sites outside the Río Cruces basin. The decline in the swan population reportedly occurred immediately after the opening, in 2004, of a large pulp mill upstream on the river, operated by Celulosa Arauco y Constitución (CELCO).

The causal link between the CELCO plant and the disappearance of the swans was made almost instantaneously. Some suggested that the changes in the wetland were caused by effluent released by the plant (UAC 2005, Mulsow \& Grandjean 2006). The public outcry prompted site visits by the RAMSAR Commission (Di Marzio \& McInnes 2005) and the World Wildlife Fund (WWF 2005).

There has been a great deal of published work on the impact of cellulose plants on the environment. Most of the impacts concern changes in oxygen levels in sediments and water as a consequence of high organic loadings, but Torre \& Masso (1975) found elevated $\mathrm{Hg}$ levels in molluscs near a cellulose plant, and Kytömaa et al. (1995) analysed an epiphytic lichen near a cellulose plant in Finland, and found high levels of (airborne) $\mathrm{Al}$ and $\mathrm{Fe}$, as well as somewhat elevated levels of $\mathrm{Hg}$ and $\mathrm{Cu}$. The CELCO plant, however, has a high-capacity tertiary treatment system: only 2 other plants in the world have this level of treatment of the waste water. The views of the plant managers and the public were far apart.

In April 2007, Baird \& Associates and personnel from the School of Geography and Earth Sciences, McMaster University, began a multidisciplinary study of the sanctuary in an attempt to understand more clearly the dynamic processes at work. This program included coring, hydrodynamic modelling, microfossil analyses, geochemical work and remote sensing. In the present study, we focused on the trace element record in bivalves living in the river. The initial purpose was to determine if there were any trace element signals in the bivalves that could be attributed to the operation of the plant. We soon discovered, however, that aspects of the evolution of this unique wetland were described by the records in the bivalves. The present study then had 2 aims: to describe trace element records in bivalves as a forensic tool to investigate putative indus- trial discharges, and identify changes in the trace element patterns as this wetland evolved.

\section{USE OF BIVALVES AS INDICATORS}

Bivalve shell fabric has been studied for more than 150 yr. Significant additions to our knowledge were made by Carpenter (1844), Prenant (1927), Bøggild (1930) and Carter (1980). Unionid bivalves have been favoured for studies of environmental change in freshwater systems because they are widespread and longlived (Dunca et al. 2005, Carroll \& Romanek 2008). The filter-feeding unionid Diplodon chilensis is widespread in Chile (Peredo et al. 2005), and was chosen as the subject of the present study. The use of biomonitors has recently been reviewed by Ravera (2001, p 69), who stated 'bivalves are very useful as "sentinels" to evaluate the importance and spatial distribution of many pollutants.'

Mark-and-recovery studies and oxygen isotope analyses have demonstrated that shell growth lines are laid down annually in most freshwater bivalve species (Negus 1966, Neves \& Moyer 1988, Veinott \& Cornett 1996). These lines allow age determination and individual growth histories (Valdovinosa \& Pederossa 2007), although timing of growth increment formation may vary greatly among localities. Most unionid growth is influenced by seasonal temperature cycles, where light bands are formed during periods of fast growth and increased water temperature (i.e. Negus 1966). The darker bands are attributed to slower growth influenced by cooler temperatures; growth can also slow as result of a decrease in nutrients and a change in diet, handling, predation and other environmental disturbances (Parada et al. 1989). The overall growth rate of Diplodon chilensis in temperate Chilean lakes is mainly influenced by temperature, nutrients and turbidity (Valdovinosa \& Pederossa 2007). Recently, Soldati et al. (2009) have demonstrated the annual nature of internal growth increments in $D$. chilensis, and found that their life span can reach $90 \mathrm{yr}$.

A study of the growth and life span of Diplodon chilensis by Parada et al. (1989) noted that specimens captured at Lake Villarrica, Chile, in the summer (January 1985 and February 1986) had dark (slow) growth rings as the most recently secreted shell. Specimens caught in the winter (July 1985) exhibited light band formation and a dark band was present by November. They concluded that this species preferentially spends its energy during the summer for reproduction (spawning and brooding of glochidia) and allocates energy to growth during the fall and winter (Parada et al. 1989). This was further verified by Soldati et al. (2009), as light-coloured austral summer increments had more positive $\delta^{18} \mathrm{O}$ values, in contrast to the austral winter 
increments that were darker and had a lower $\delta^{18} \mathrm{O}$ values, thus confirming the annual cyclicity of growth increment formation.

Although bivalves have shown themselves to be accurate recorders of ambient water conditions, great care must be exercised in interpreting the results from a new locality. The factors forcing growth increment formation can be many, and will vary from place to place. At each locality, timing of formation of increments must independently be established, either through time of sampling or mark-and-recovery (the discussion in Arnold et al. 1998 provides an overview of the problems involved). Verification of timing of events is especially important given the forensic possibilities of bivalve shell analysis. In one of the first efforts in this field, Bourgoin (1990) was able to establish the location of $\mathrm{Pb}$ ore stockpiled near a harbour on the east coast of Canada.

\section{MATERIALS AND METHODS}

Field sampling. Diplodon chilensis were collected at 6 sites: 2 in the Río Calle Calle, a tributary of the Río Cruces, and 4 from the Río Cruces proper (Fig. 1). Bivalves were found at depths of 1 to $3 \mathrm{~m}$, in fine sands with an algal overlay, and were collected by snorkelling. Usually, 5 to 6 individuals were taken at each site. We were unable to find bivalves in the muddy, low shear strength sediments of the sanctuary.

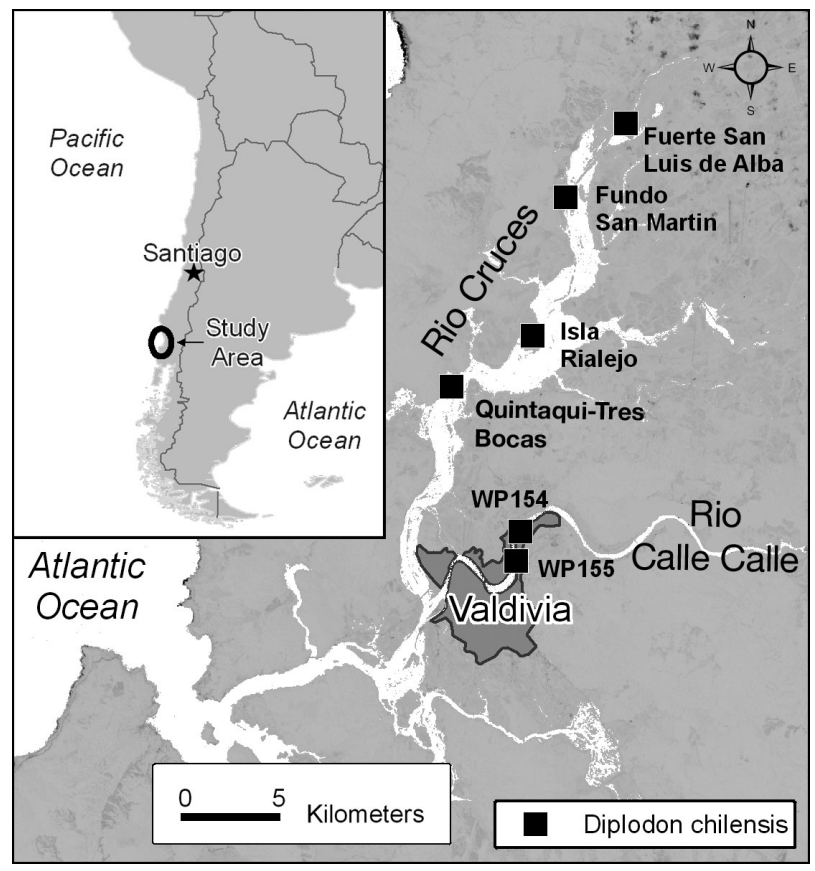

Fig. 1. Rio Cruces, Chile, including study locations (ם) where Diplodon chilensis bivalves were collected
Bivalves were shucked of their meat, the shells rinsed in freshwater, dried and shipped to Canada for analysis. All bivalve material not destroyed through analysis is archived with the School of Earth Sciences, McMaster University, or with the senior author.

Thin-section preparation and age assessment. A total of 6 Diplodon chilensis shells were scrubbed with a soft brush and sonicated in distilled water for $20 \mathrm{~min}$ to remove any surface debris. Specimens were cut perpendicular to the umbo along the axis of maximum growth towards the ventral margin of the shell. The shell halves were set in 5:1 ratios of Buehler Epoxycure resin and hardener. Once the embedding material was completely cured, the samples were cut using a Buehler ISOMET low-speed saw with a diamond blade, polished, sonicated and rinsed with distilled water. Polished cross sections of shells were mounted onto microslides using Hillquist thin-section epoxy, cut a second time and polished again on a glass plate using Buehler 0.3 micron alpha-alumina micropolish. Polished shells were sonicated again, rinsed in ethanol and air-dried before mounting cover slips with Canada Balsam and final oven-curing.

Thin sections of shells were visualized and photographed with a 12 megapixel Nikon camera affixed to a SMZ800 Nikon stereomicroscope and photographed using ACT-1 image software. Age of shells was established by counting the number of combinations of light/dark annuli from the ventral margin of the shell towards the umbo. It was assumed that each couplet of light/dark lines represents $1 \mathrm{yr}$, since it was previously established that dark bands form in the summer and lighter bands form in the winter (Soldati et al. 2009). The ontogenetic age was calculated by counting the combinations of light/dark annuli from the ventral margin of the shell towards the umbo.

Trace element analysis. Immediately on returning to Canada, representative bivalve shells from all sample locations were shipped to Memorial University of Newfoundland (MUN) for analysis at the MicroAnalysis Facility-Inco Innovation Centre (MAF-IIC). The inner and outer surfaces of the shells were scrubbed with a nylon brush and distilled water to remove adhering sediment and debris, followed by an ultrasonic bath in distilled water. Shells were sectioned from the umbo to the margin, along the axis of maximum growth, with a slow speed sectioning saw. After air drying, the bivalves were mounted in epoxy blocks $(47 \times 27 \times 5 \mathrm{~mm})$. The epoxy mounts were then ground flat and polished with increasingly finer polishing material to a final $3 \mu \mathrm{m}$ medium (Fig. 2). Samples were ultrasonically cleaned in deionized water before being analysed. A flat bed scanner was used to create 'maps' or images of the bivalves to locate positions of laser scans. The scans for which results are reported herein 


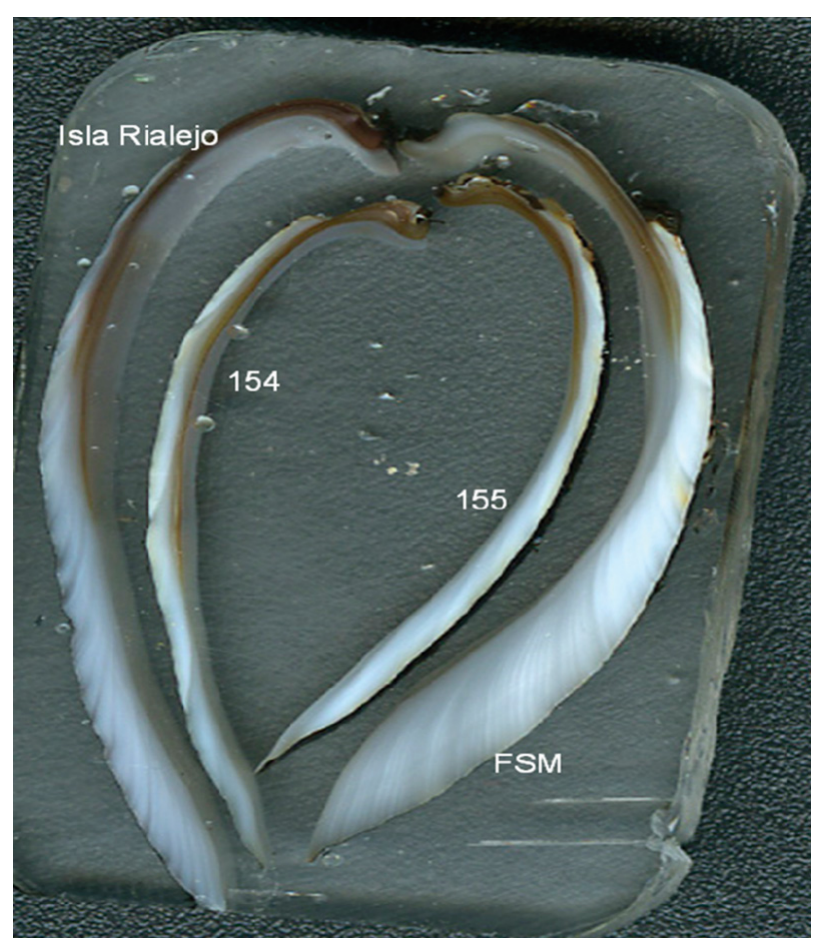

Fig. 2. Diplodon chilensis. Shells sectioned, mounted and polished for laser ablation inductively coupled plasma mass spectrometry (LA-ICP/MS) analysis. FSM: Fundo San Martín. Shells WP154 and WP155 are from younger D. chilensis from the Río Calle Calle

were taken in the middle part of the shell, as suggested by Soldati et al. (2009).

Concentrations of 15 elements $-{ }^{24} \mathrm{Mg},{ }^{43} \mathrm{Ca},{ }^{49} \mathrm{Ti}$, ${ }^{55} \mathrm{Mn},{ }^{57} \mathrm{Fe},{ }^{63} \mathrm{Cu},{ }^{66} \mathrm{Zn},{ }^{75} \mathrm{As},{ }^{88} \mathrm{Sr},{ }^{111} \mathrm{Cd},{ }^{118} \mathrm{Sn},{ }^{121} \mathrm{Sb}$, ${ }^{137} \mathrm{Ba}^{205} \mathrm{Tl}$ and ${ }^{206} \mathrm{~Pb}$ - were determined at MUN using laser ablation inductively coupled plasma mass spectrometry (LA-ICP/MS). The analytical system is a Finnigan ELEMENT XR, a high resolution double focusing magnetic sector inductively coupled plasma mass spectrometer (HR-ICP/MS) coupled to a GEOLAS $193 \mathrm{~nm}$ excimer laser system. A helium flow rate of 0.9 to $1.0 \mathrm{l} \mathrm{min}^{-1}$ was used to carry ablated material to the ICP, with an additional $0.561 \mathrm{~min}^{-1}$ Ar make-up gas added after the ablation cell. The $40 \mu \mathrm{m}$ laser beam was rastered at 10 and $15 \mu \mathrm{m} \mathrm{s}^{-1}$ (depending on the resolution needed) over the bivalves to produce pro- files across the growth lines. Laser energy was approximately $3 \mathrm{~J} \mathrm{~cm}^{-2}$ and the laser repetition rate was $10 \mathrm{~Hz}$. Time-resolved intensity data were acquired by peak-jumping in a combination of pulse-counting and analog modes, depending on signal strength, with one point measured per peak for masses. Concentrations were calibrated with the NIST 612 glass. Calcium oxide $(\mathrm{CaO})$ was the internal standard used to deal with differences in ablation yields and matrix effects between the unknown bivalves and the calibration materials (NIST glasses). The CaO concentration of the unknowns was assumed to be homogeneous at 55.0\%. Approximately $30 \mathrm{~s}$ of gas background data were collected prior to each laser raster of both standards and unknowns. All samples were preablated at $30 \mu \mathrm{m} \mathrm{s}^{-1}$ (without collecting data) to ensure the sample surface was free of any contamination due to sample preparation or cleaning.

The data acquisition methodology employed an analytical sequence of 2 analyses of the NIST 612 standard and one of Macs1 reference material with analyses of up to 14 unknown bivalves, closing with a repetition of the same standards in reverse order. The Macs1, a similar matrix to the bivalves, was treated as an unknown and data were acquired to allow the monitoring of accuracy and precision of the data set and the technique in general. The error for the method when measuring homogeneous materials is estimated to be $<4 \%$ relative, based on the reproducibility of results for various reference materials measured from day to day over several months in the MUN laboratory. Average limits of detection for the various elements are provided in Table 1.

Data were reduced using MUN's in-house CONVERT and LAMTRACE spreadsheet programs, which employ procedures described by Longerich et al. (1996). In order to establish estimates of within-sample variability, several parallel traces $1 \mathrm{~mm}$ apart were performed on the same shells. In order to obtain even greater resolution for the period 2000-2008, a slowspeed scan was taken of the outer part of 1 shell from Fuerte San Luis de Alba. This scan trace is shown in Fig. 3, in order to illustrate the resolution. Although high temporal resolution and instrument precision are possible, it must be emphasized that only relative trace

Table 1. Detection limits (ppm) of the laser ablation inductively coupled plasma mass spectrometry (LA-ICP/MS) instrumentation for selected elements; nd: no data

\begin{tabular}{|lcccccccc|}
\hline Date of analysis & $\mathrm{Mn}$ & $\mathrm{Fe}$ & $\mathrm{Cu}$ & $\mathrm{Zn}$ & $\mathrm{As}$ & $\mathrm{Sr}$ & $\mathrm{Ba}$ & $\mathrm{Pb}$ \\
\hline 18 Jun 2008 & 0.0 & nd & 0.0013 & 0.0054 & 0.0027 & 0.0036 & 0.0026 & 0.003 \\
14 Jul 2008 & 0.0 & 2 & 0.0094 & 0.0236 & 0.0221 & 0.0263 & 0.0090 & 0.0012 \\
29 Jul 2008 & 0.0 & 0.6 & 0.00476 & 0.0153 & 0.0069 & 0.0081 & 0.00376 & 0.00119 \\
10 Sep 2008 & 0.1 & 0.6 & 0.00476 & 0.0104 & 0.0122 & 0.00801 & 0.00621 & 0.00070 \\
\hline
\end{tabular}


element data are reported herein. Estimates of absolute levels of trace element concentrations were beyond the budget available.

Trace element data reduction and comparisons. Digital trace element data from separate scans along a track from the same bivalve were stitched together at MUN. Negative values were zeroed out. By carefully recording the start time, location and direction of the trace element scans, we were able to overlay the trace element data onto photographs of the growth banding patterns. This established the annual cyclicity of several of the trace elements, especially $\mathrm{Sr}, \mathrm{Ba}$ and $\mathrm{Mn}$. These 3 elements are strongly correlated with annual environmental signals such as river discharge (e.g. Gillikin et al. 2005, Pearce \& Mann 2006). This allowed us to match the trace element cycles of $\mathrm{Mn}, \mathrm{Sr}$ and Ba with river discharge using Grapher ${ }^{\circledR}$, a software plotting package of great flexibility which allows portions of cyclic data patterns to be stretched or compressed. This was necessary because the growth rates of the bivalves varied a great deal. For the first $10 \mathrm{yr}$ or so, they grow rapidly, often adding increments of $>1 \mathrm{~mm} \mathrm{yr}^{-1}$. Later senescent growth is much slower, usually 3 to $4 \mathrm{yr} \mathrm{mm}^{-1}$ (Fig. 4).

The scan location for each bivalve was used to correlate the start of the discharge record at Rucaco gauging station (CELCO unpubl. data) with the start of the trace element scan. Visual inspection of the scan location and corresponding dates were determined. The scan from the bivalves from Fuerte San Luis de Alba and Quintaqui-Tres Bocas started in shell material equivalent to the spring of 2007, while the scan of the bivalve shell from Fundo San Martín started in shell laid down in the spring of 2008. Hydrologic data on flow of the Río Cruces were obtained from the Chilean Ministerio de Obras Publicas, Direccion General de Aguas. Matching the start of the scan lines with the banding pattern and the growth bands provides an independent assessment of time resolution. During periods of high discharge the bivalves are

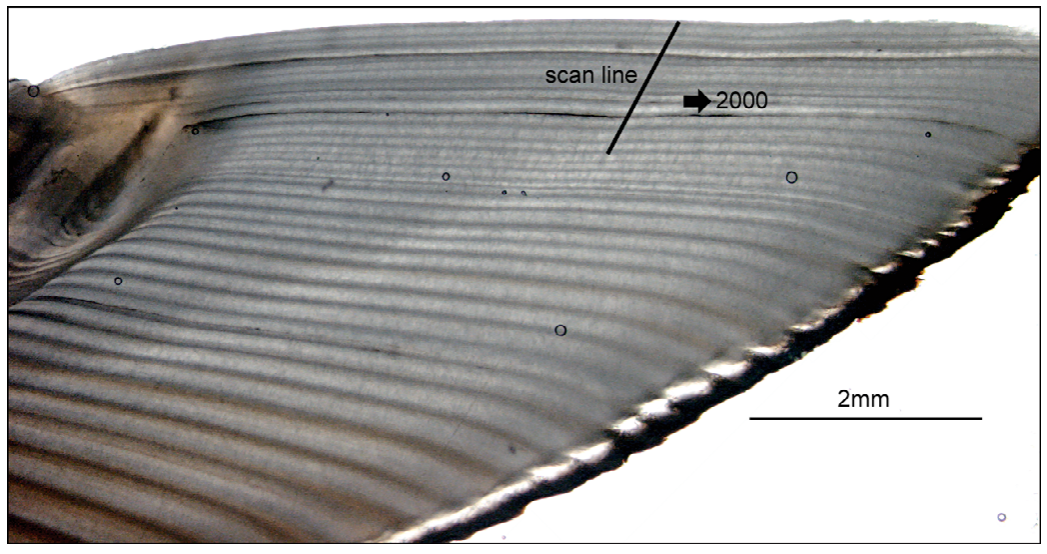

Fig. 3. Diplodon chilensis. Micrograph of the distal margin of a sample from Fuerte San Luis de Alba, prepared for LA-ICP/MS scans to provide trace element data for the period $\sim 1992$ to 2008. Scan location is given, as well as level of the shell corresponding to 2000

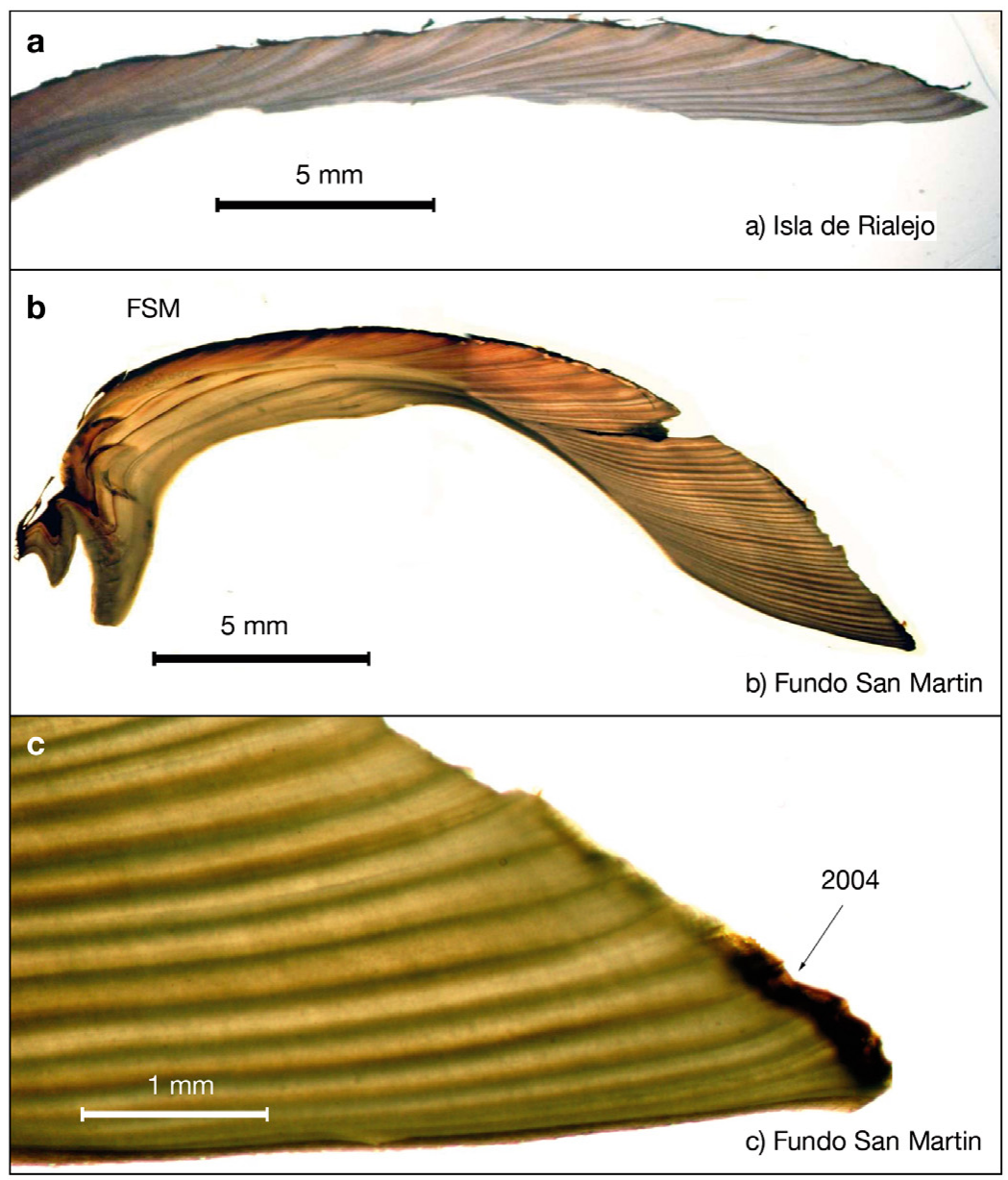

Fig. 4. Diplodon chilensis. Micrographs of selected examples. (a) Cross section of young bivalve from Isla Rialejo; (b) cross section of mature bivalve from Fundo San Martín; and (c) cross section of mature bivalve from Fundo San Martín, larger magnification. Note location of shell laid down in 2004, and sub annual banding in some years 
adding shell, as may be seen from the close correspondence between the trace element records and the discharge records. The timing of events occurring during high discharge can then be established to within a few weeks. On the other hand, the bivalves may cease shell growth during other parts of the year, reducing precision of event identification.

\section{RESULTS}

\section{Description of growth increments}

All of the bivalves except very young individuals showed clear, pronounced growth increments, present as alternating dark/light couplets, consistent with the observations of Soldati et al. (2009). Specimens were collected in late April 2008, at the end of the austral summer, and exhibited a dark band at the ventral margin. Examples of the growth patterns found in the shells are given in Fig. 4. With higher magnification, subannual growth increments could be seen even in the narrow growth bands of recent years.

Samples from Fundo San Martín and Fuerte San Luis de Alba had life spans of almost 50 yr. Some examples from further downriver, closer to the muddy substrates of the wetland, were much younger, in some cases
$<10 \mathrm{yr}$ old. Extension rates of the older bivalves were on the order of $200 \mu \mathrm{m}$ per year; that is, there were generally 4 to 5 growth couplets per $\mathrm{mm}$. These rates are considerably higher than the rates found in Diplodon chilensis patagonicus by Soldati et al. (2009) from Andean lakes and rivers, which grew only $0.05 \mathrm{~mm} \mathrm{yr}^{-1}$.

\section{Trace element scans}

LA-ICP/MS scans produce enormous amounts of data, and more than 70 scans were performed for the present study. A summary will be provided here: supplemental material available at www.int-res.com/articles/suppl/ b010p085_supp.pdf. Elements scanned for were Mg, Ca, $\mathrm{Ti}, \mathrm{Mn}, \mathrm{Cu}, \mathrm{Zn}, \mathrm{As}, \mathrm{Sr}, \mathrm{Cd}, \mathrm{Sn}, \mathrm{Sb}, \mathrm{Ba}$, Ti and Pb. In general, levels were all relatively low, perhaps reflecting the low population density of humans in the watershed. Only those metals exhibiting significant patterns or anomalies will be discussed herein. Bivalve shells from time to time may contain small inclusions of foreign matter (Kennedy et al. 1969), so peaks that were primarily driven by 1 or 2 data points are not considered to be significant. The results of parallel scans run on the same shell (Fig. 5) allow estimation of the quality assurance on the trace element data. Both scans agree in the height

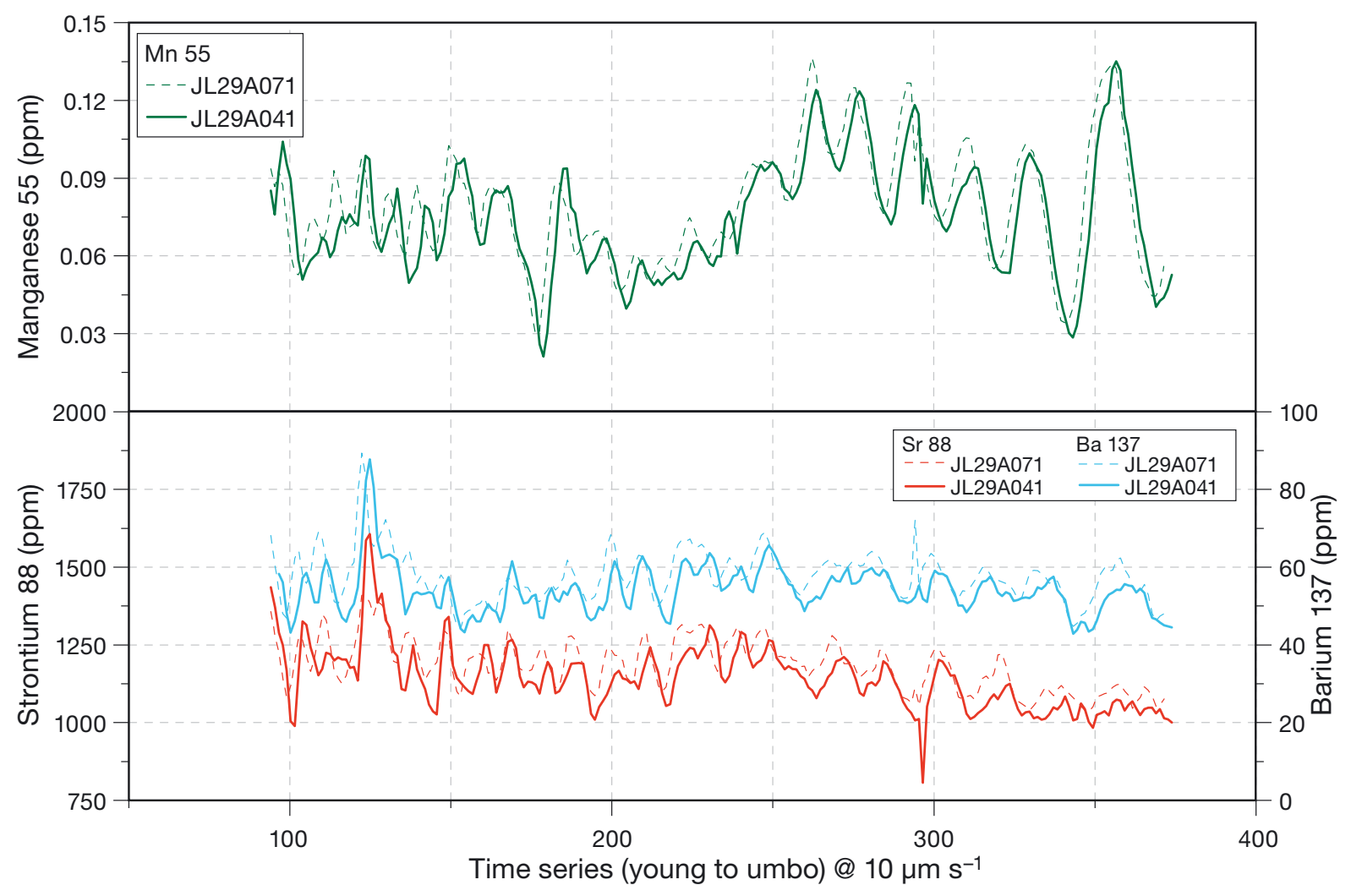

Fig. 5. LA-ICP/MS replicate scans across shells of Diplodon chilensis from Fuerte San Luis de Alba 


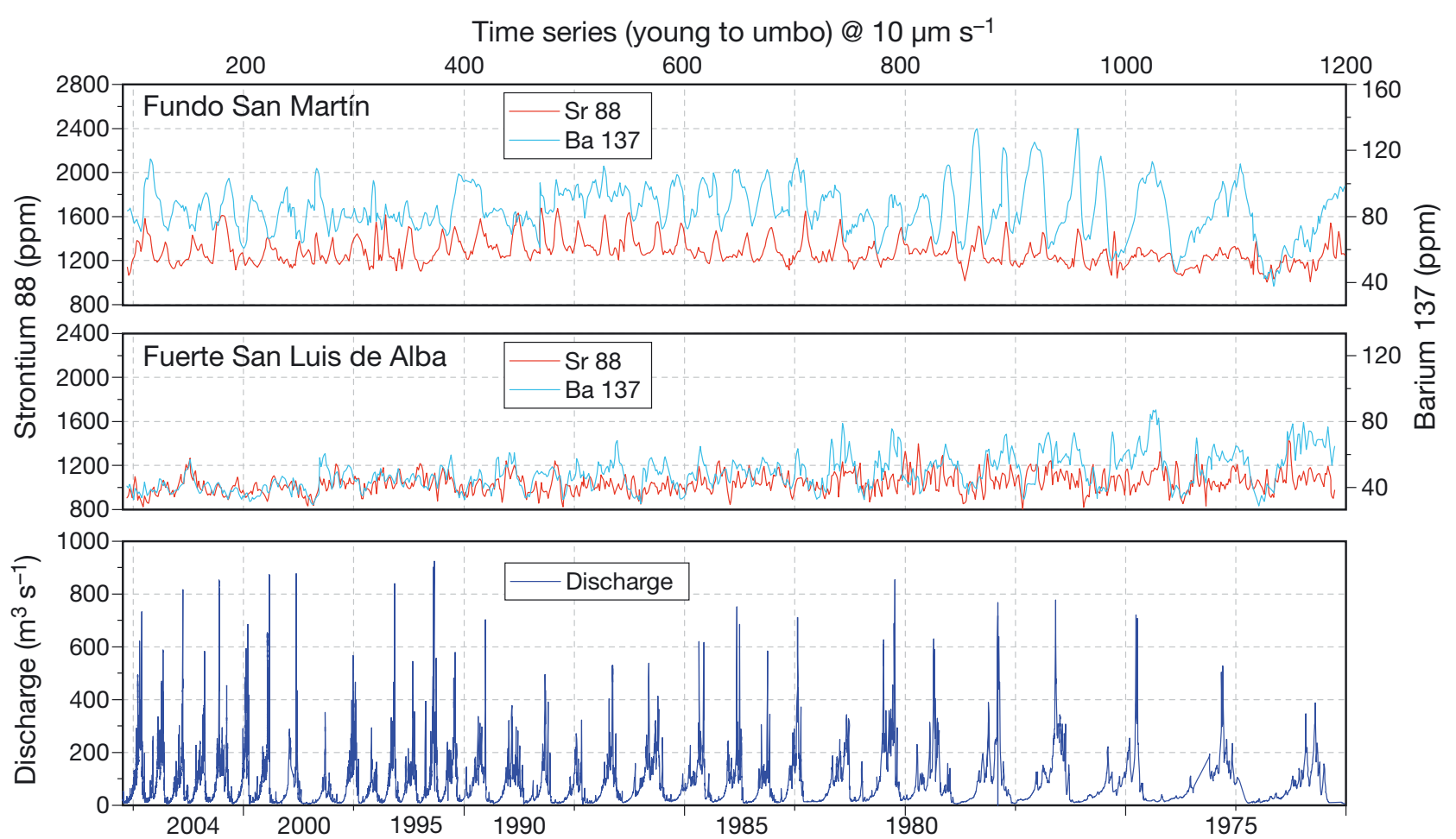

Fig. 6. LA-ICP/MS scans across shells of Diplodon chilensis from Fuerte San Luis de Alba and Fundo San Martín, showing cyclicity in $\mathrm{Sr}$ matched by cyclicity in $\mathrm{Ba}$, with minor peaks in other trace elements. Scans have been matched to the discharge record of the Río Cruces

and periodicity of levels of all metals; the error between readings was generally on the order of $<1 \mathrm{ppm}$.

Sr was the most abundant trace metal, with levels on the order of 1000 to $1500 \mathrm{ppm}$. Sr levels were periodic, with cycles ranging from a low of $900 \mathrm{ppm}$ to a high of 1400 ppm. Ba was present at much lower levels, but also occurred in cycles, with the periodicity matching that of Sr. This was the case in all the bivalves studied (Fig. 6). Mn also exhibited the same periodicity, although $180^{\circ}$ out of phase with Sr and Ba.

In many of the scans, $\mathrm{Cu}$ began to appear at values above baseline at time periods in the mid- to late 1970s. Cu values showed annual cyclicity, and peaked at approximately 100 ppm (Fig. 7), although typical values were much lower. Fig. 7 also shows the progressive change in the nature of the Ba record. Immediately after the earthquake, and for some years after (until about 1970), Ba showed large, broad peaks. This pattern gradually changed, and after 1980 the Ba peaks were smaller. In bivalves from both Fuerte San Luis de Alba and Fundo San Martín there was a small, simultaneous peak at values of $5 \mathrm{ppm}$ in $\mathrm{Cu}$, occurring in 1984. Levels of As were typically low at $<1 \mathrm{ppm}$. Nonetheless, in one scan from Fundo San Martín, values have increased from essentially zero to approximately 1 ppm since the mid-1990s.
In the record from Fuerte San Luis de Alba (Fig. 7), there were minor upward excursions in $\mathrm{Zn}, \mathrm{Pb}$ and $\mathrm{Cu}$, which occurred in 2004. Much larger values of these metals were recorded earlier. Bivalves from Fundo San Martín, downstream, showed no signs of these minor upticks.

\section{DISCUSSION}

\section{Trace element considerations}

Local conditions and element provenance

This part of Chile receives a good deal of rainfall, especially in the austral winter. As recorded at Planta Valdivia, more than $300 \mathrm{~mm}$ of rain falls in each of May, June and July; during the 6 mo rainy season, more than $1.5 \mathrm{~m}$ falls on the study area out of an annual total of $\sim 2 \mathrm{~m}$. As a consequence, levels and flow velocities of the Río Cruces fluctuate greatly during the course of a year: riverine inflow to the wetland varies from $>400 \mathrm{~m}^{3}$ $\mathrm{s}^{-1}$ in July-August to $<50 \mathrm{~m}^{3} \mathrm{~s}^{-1}$ in February-March (Rucaco gauging station; CELCO unpubl).

Because of the $2 \mathrm{~m}$ downwarping of the river bed caused by the faulting, sediment deposition rates are 


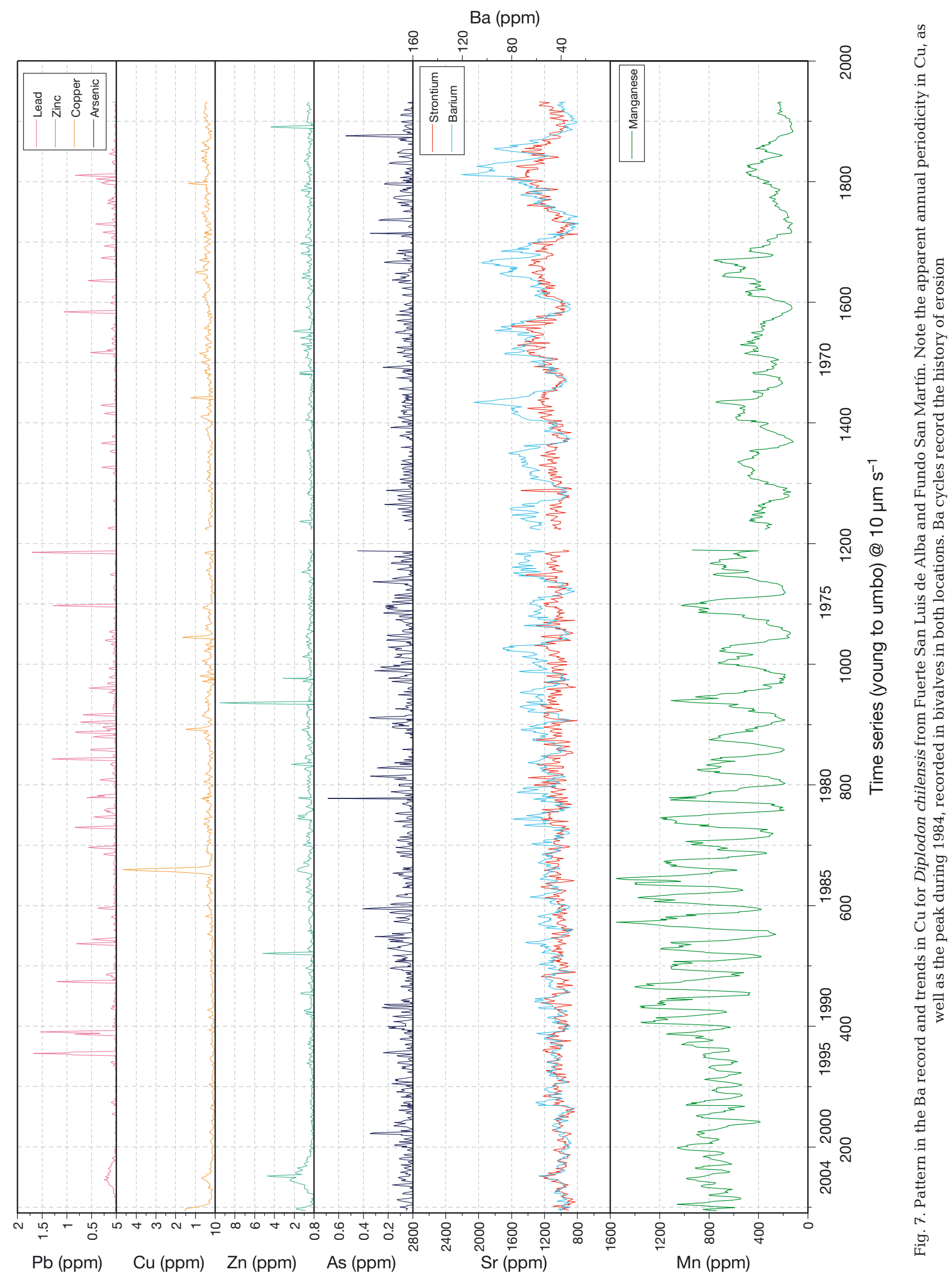


extremely high, usually exceeding $2 \mathrm{~cm} \mathrm{yr}^{-1}$ (Reinhardt et al. 2010). Upstream riverbeds are covered with thick mats of cyanobacteria; this material is eroded during high flows and deposited in the wetland. To this allochthonous contribution of organic matter is added an autochthonous contribution from phytoplankton in the sanctuary. Consequently, the sedimentary setting in the wetland is characterised by high deposition rates of organic-rich sediments, rapid onset of reducing conditions in the subsurface and intermittent erosion and deposition driven by flood events and wind-driven surface currents. It is likely that these factors influence the trace element distributions found in the bivalves.

In addition, because of the high erosion and deposition rates, the chemical nature of the sediment sources needs to be considered. The limits of the present study did not allow for detailed watershed analysis and sediment provenance determinations. Nonetheless, there is limited information available. Most of the basin is covered by a thick infilling of unconsolidated alluvial and volcanogenic deposits, derived in turn from a line of Late Cenozoic andesitic volcanoes (Plafker \& Savage 1970). The fact that the majority of the sediments carried down the Río Cruces and entering the sanctuary are derived from andesitic volcanic rocks, and the deposits derived from them, will affect the suite of trace elements carried down the river. Levels of both Ba and Sr are very low in basic and ultrabasic rocks. Values of both elements increase in metamorphic schists and gneisses, andesites, carbonate rocks and clay-rich sediments. Some flood plain deposits record values of $450 \mathrm{ppm}$ for Ba and $870 \mathrm{ppm}$ for Sr (Aubert \& Pinta 1977). In a study of rivers draining from the Himalayas, Dalai et al. (2002) found that Ba was associated with organic matter and was released during weathering and erosion. Biological cycles aside, it may be anticipated that there would be annual cycles in trace element input to the wetland driven by cycles of weathering, erosion and rainfall.

\section{Trace element record in Diplodon chilensis}

Trace element profiles in the shells of Diplodon chilensis show that $\mathrm{Sr}, \mathrm{Ba}$ and $\mathrm{Mn}$ all have strong annual cycles. Sr in the bivalve shells fluctuates around values of $\sim 1200 \mathrm{ppm}$, with high values of about $1600 \mathrm{ppm}$ and low values of $\sim 800 \mathrm{ppm}$. These values are somewhat higher than those reported by Soldati et al. (2009). High values of Sr occur during the austral summer; the Sr cycles may be driven by temperature fluctuations or by productivity cycles (which in turn may be driven by temperature). The origin of the cyclicity of $\mathrm{Sr}$ in these bivalves is as yet unknown.
Lazareth et al. (2003) suggest that Sr cycles in Kenyan mangrove mussels are driven by temperature fluctuations.

The change in the nature of the Ba records from the period immediately after the earthquake to more recent years probably reflects changes in the erosion pattern of the system, in a similar fashion to the records of $\mathrm{Ba}$ in corals as indicators of soil erosion (McCulloch et al. 2003, Sinclair \& McCulloch 2004). Immediately after the earthquake, the erosion rates would have been very high because the upper part of the river was cutting to a new base level. Ba records from Fuerte San Luis de Alba and Fundo San Martín show a decrease since approximately 1970. At Fundo San Martín, the furthest upstream site, annual excursions in Ba have a range of $\sim 1000 \mathrm{ppm}$ in the early 1970 s, whereas by the early part of the 21st century the amplitude had decreased to 200 ppm (Fig. 6). At Fuerte San Luis de Alba, further downstream (just at the upper part of the sanctuary), the Ba levels also show pronounced change, with excursions in the early 1970s on the order of $1200 \mathrm{ppm}$ and amplitudes post-2000 of only $200 \mathrm{ppm}$ (Fig. 7). Note that in both cases, the peaks are very broad in the period immediately after the earthquake. This reflects the growth rate of the bivalves; in fact, the trough-to-trough distance in the Ba signal is a measure of bivalve growth rate. The high Ba levels indicate high amounts of soil erosion. Over time, the nature of the cycles in Ba changes to a pattern of shorter duration and smaller amplitude. The duration is a function of rate of accretion of the bivalve shell (by this point the bivalves have entered senescent growth, and annual bands are closely spaced), but the decrease in amplitude reflects decreasing $\mathrm{Ba}$ input. In this respect, the trace elements provide information on the sedimentological history of this depositional basin. Values of Ba in the present study are considerably higher than those reported by Soldati et al. (2009), which may reflect differences in sediment provenance as well as rates of erosion.

$\mathrm{Mn}$ is closely related in its chemical behaviour to Fe (Stumm \& Morgan 1981). Both are easily mobilised when in the reduced form, but relatively insoluble when oxidised. Mn is viewed as an indicator of soil erosion and/or river discharge, because of its close association with clays and, especially, organic matter. Mn mobility in aquatic systems is governed largely by $\mathrm{pH}-$ Eh equilibria. In aerobic, neutral waters, Mn exists largely as insoluble oxide and hydroxide. Under reducing conditions, $\mathrm{Mn}$ is soluble and mobile (preceding discussion abstracted from Stumm \& Morgan 1981). It is likely that the tight correlation in the bivalve shells of $\mathrm{Mn}$ and river discharge comes from erosion and downstream transport of Mn-bearing sediments. 
In the present study, the Mn records are out of phase with $\mathrm{Sr}$ and $\mathrm{Ba}$. These summer peaks in $\mathrm{Sr}$ and $\mathrm{Ba}$ and winter peaks in Mn were also observed by Soldati et al. (2009). This may reflect differences in mobility of these elements. Sr and Ba are liberated primarily by weathering, which will be most rapid during warmer months. $\mathrm{Mn}$, on the other hand, is mobile in reduced sediments and immobile when oxidised. During high flows, in the austral winter, sediments will be eroded, liberating soluble species of Mn.

Similarly, the $\mathrm{Cu}$ record may reflect agricultural activity in the watershed. $\mathrm{Cu}$ is an important component in many fungicidal sprays (Brown et al. 1996), the use of which is widespread in Chile, and is also a contaminant from mining activities (De Gregori et al. 2003). If the record of $\mathrm{Cu}$ in these bivalves reflects agricultural activity, then it suggests that these sprays came into common usage along this watershed in the mid1970s. Cu also occurs in annual peaks, which would suggest delivery to the river by surface water. There is a spike in $\mathrm{Cu}$ values in 1984 that appears in the records from both Fundo San Martín and Fuerte San Luis de Alba. Although the actual values are low (a few ppm), this may represent some sort of spill that affected much of the river. There is one record, from Fundo San Martín, that shows a slight increase since the earthquake in values of As which, like $\mathrm{Cu}$, is a common component of pesticide sprays (Pershagen 1981).

There are minor upticks in $\mathrm{Zn}, \mathrm{Pb}$ and $\mathrm{Cu}$ in one scan from Fuerte San Luis de Alba, to values that are barely above baseline: $\mathrm{Zn} 4$ ppm, Pb 2 ppm and $\mathrm{Cu} 1$ ppm (Fig. 7). These values are less than values for the same metals recorded from earlier years, but may reflect some as yet unidentified industrial input. These upticks were not recorded at Fundo San Martín, $5 \mathrm{~km}$ downstream, and therefore cannot be regarded as representing significant input to the sanctuary.

\section{Bivalve growth and ecology}

There has been excellent work done on trace elements in watersheds in general, and in bivalves in particular (e.g. Rubio et al. 2000, Saavedra et al. 2004, Perceval et al. 2006, Peltier et al. 2008). Some of the issues raised in the present study are also addressed by Soldati et al. (2009), which discusses growth and shell chemistry of a subspecies of the bivalve used in the present study. The section of the Río Cruces described in the present study is a unique wetland, having been created in a few days by the largest earthquake in history. This has influenced the depositional style of the sediments and the rate of supply of dissolved and particulate matter. There may be parallels with another unique depositional environment, the Windsor mud- flat, Nova Scotia (Amos 1977, Turk et al. 1980, Risk \& Yeo 1980).

The Windsor mudflat was not created by an earthquake, but by the construction of a solid rock causeway that occluded the tidal prism of the Bay of Fundy, famous for its high tides. During buildup of the Windsor mudflat, sediment accretion rates were 5 to $14 \mathrm{~cm}$ $\mathrm{mo}^{-1}$, more than $1 \mathrm{~m} \mathrm{yr}^{-1}$. As a consequence of these rapid sedimentation rates, water content of the sediment was very high and shear strengths very low - a situation analogous to the sediments in the Río Cruces. Because of the rapid sediment accumulation rates, organic matter is buried quickly and anoxia sets in at a depth of a few $\mathrm{mm}$. The organic content of the Windsor mudflat is higher than that of a typical Bay of Fundy mudflat, again analogous to the Río Cruces.

The eventual fate of mudflats such as that at Windsor is that they dewater and eventually become colonised by marsh grasses. At the Windsor mudflat, there are indications that this is happening: over the course of a summer, the water content of the sediments drops by about $10 \%$. Emergent vegetation is starting to colonize the flat, but each year some is destroyed by winter ice.

In addition to high accretion rates, organic carbon content is also high, reducing conditions are common and the ecology of the bivalves in the Windsor mudflat is affected by the low shear strength of the sediments. The water content of the sediment is so high and the shear strengths so low that bivalves simply sink into oblivion once they reach a critical size. This may be the situation in the Río Cruces.

Divers were unable to find any examples of Diplodon in the lower part of the Río Cruces, despite several days spent searching. The furthest downstream occurrences were at Quintaqui-Tres Bocas and Isla Rialejo, more than $15 \mathrm{~km}$ upstream of Valdivia and about halfway down the Río Cruces. These specimens were much younger than the examples found upstream: 6 to $10 \mathrm{yr}$ compared to $\sim 50 \mathrm{yr}$. It is possible that our sampling scheme simply failed to find old bivalves in the main part of the Río Cruces. On the other hand, by analogy with the Windsor mudflat, it would be logical to assume that the Río Cruces, for years after the earthquake, could not support bivalves the size of Diplodon. That young bivalves may now be found in the lower Río Cruces suggests that it is undergoing natural succession as the sediments dewater.

The bivalves in the present study grew rapidly for the first decade or so, and then growth slowed as the animals became senescent. Our results are in concordance with the isotopic study of Soldati et al. (2009), in which dark winter bands are associated with more positive $\delta^{18} \mathrm{O}$. Temperature regimes in the 2 study areas are similar: air temperature ranges of 2 to $16^{\circ} \mathrm{C}$ (Soldati et al. 2009) versus 7 to $16^{\circ} \mathrm{C}$ (present study). 


\section{Relationship between bivalve records and disappearance of swans}

There is a large body of scientific literature attesting to the rapid response of metal content of lakes and rivers following changes in the water chemistry, such as increasing acidity. Lucassen et al. (2002) found that metal content of water increased within 1 wk of a $\mathrm{pH}$ change. The study of impacts of acid mine drainage are illustrative, because they demonstrate the sudden increase in metals in the water following increases in acidity (e.g. Manzano et al. 1999, Sherrell \& Ross 1999, Achterberg et al. 2003). In addition, the shells of bivalves have been shown to record short-lived chemical events. In one of the earliest papers on this subject, Bourgoin (1990) found that the location of piles of ore stockpiled on shore for loading onto freighters could be traced by analysing local Mytilus shells. More recently, Pearce \& Mann (2006) showed that the shells of razorclam Ensis siliqua from British waters are sensitive recorders of general metal pollution, as well as of short-lived phenomena. They state (p. 750) that concentrations of $\mathrm{Pb}, \mathrm{Zn}, \mathrm{Cd}$ and $\mathrm{U}$ 'show no systematic seasonal behaviour, and form in response to relatively short-lived changes (weeks to months) in metal concentrations in the overlying waters.'

Mulsow \& Grandjean (2006, p. 9) postulated that a sulphate spill from the CELCO plant disrupted the physiology of the weed, leading to the disappearance of the swans: 'A similar phenomenon must have occurred in the Sanctuary after the CELCO pulp mill began operations in January-February 2004'. This hypothesis was refuted by Harding et al. (2007), who pointed out that it was chemically impossible, and by Soto-Gamboa et al. (2007), who found errors in the experimental design, statistical procedures and physiological postulates of Mulsow \& Grandjean (2006). Soto-Gamboa et al. (2007, p. 3) concluded: 'Furthermore, in our comment on the chemistry we have shown that sulphate and bicarbonate are compatible and not negatively related as proposed by Mulsow \& Grandjean (2006). Both observations allow us to conclude that the unrealistic and reduced repeatability of their experimental design ... has no empirical or theoretical basis.'

Notwithstanding this refutation of the original hypothesis, in a recent paper (Mulsow et al. 2009, p. 177) the postulated original spill has morphed into an actual event: 'Historically, this river suffered a strong chemical change early in the year 2004 caused by pulp mill waste water unauthorized releases (black liquor).' Mulsow et al. (2009, p. 178) reported heavy metal excursions in their 3 cores that they state 'clearly represent remobilisation of the tracer caused by a chemical shift in the water column.'
The chemical spill has never been proven, only postulated by Mulsow et al. (2009). Their hypothesis would involve large changes in the chemistry of the water column, which — as outlined above - would be accompanied by changes in the trace element suite. From the records in the bivalves, there is no evidence for a basinwide chemical spill associated with the opening of the plant. It is difficult to imagine a 'chemical shift in the water column' that left no record. The hypothesis of Mulsow \& Grandjean (2006), and any similar hypothesis involving massive chemical spills, now seems improbable. The disappearance of the luchecillo and the swans must be explained in some other fashion. It appears that the decline of the weed occurred during the process of typical wetland succession, as the environment grew less favourable for its growth.

\section{Bivalve sclerochronology in environmental forensics}

Given present trends in industrial development, and the possible environmental costs, there has been recent growth in the field of environmental forensics, the use of tools by which contaminants may be identified and fingerprinted (Pye \& Croft 2004, Murphy \& Morrison 2007). Much of the written material to date has dealt with hydrocarbon spills and contamination, with emphasis on applications such as GC-MS. In terms of inorganic chemistry, Slater (2003) emphasized the importance of single-compound stable isotope analyses, and Durrant \& Ward (2005) outlined the potential importance of LA-ICP/MS.

In any forensic investigation, it is important to establish the nature and timing of the crime, as well as the culprit. In environmental investigations, the crime will usually be discharges of metals, nutrients or hydrocarbons. It would seem that bivalves are almost uniquely able to provide useful data in at least one of these fields, i.e. identification and fingerprinting of metals. The stratigraphic resolution available from bivalves exceeds virtually all other sources of data: annual resolution is easy, and monthly resolution is possible. Isotopic ratios can be used, in some cases, to provide further data allowing sources to be identified.

The disappearance of the swans from the Río Cruces wetland was a phenomenon that occupied several agencies and universities, stirred intense public feeling and spawned at least one court case. Debate hinged around the proposed existence of an unauthorised spill, one that supposedly killed the weed on which the swans fed. It would appear that much of the debate has now been put to rest by the testimony of the bivalves. There will be other examples, no doubt, which would benefit from the existence of long-lived elemental 'tape recorders'. 


\section{CONCLUSIONS}

(1) Shells of Diplodon chilensis from the Río Cruces exhibit strong annual banding, verified by stable oxygen isotope analysis, thin-section observations and trace element cycles. Stratigraphic resolution is excellent.

(2) Trace element concentrations in the shells of bivalves from the Río Cruces provide data on the evolution of the watershed following an earthquake. Sr exhibits strong annual cyclicity, which may track temperature fluctuations. Ba is proposed as an indicator of soil erosion and/or sediment production. $\mathrm{Mn}$ is mobilised under reducing conditions, and its concentration in the river waters probably indicates erosion of anoxic sediments during high flow events.

(3) Ba fluctuations in the years immediately after the earthquake were large, suggesting sudden increases in soil erosion. More recent Ba peaks are smaller, as the river is cut down to base level.

(4) $\mathrm{Cu}$ begins to appear in the records in the mid1980s, and exhibits annual cycles. This may reflect the use of antifungicidal sprays. Similarly, a minor uptick in As in a record from Fundo San Martín may also reflect agricultural impact.

(5) There is no record in the bivalve shells of a widespread chemical spill corresponding to the opening of the CELCO Plant.

Acknowledgements. This work was funded by a contract between Forestal Arauco and Baird and Associates, and by grants to M.J.R. awarded by the Natural Sciences and Engineering Research Council of Canada. Thin section and image preparation was completed at the Fisheries Archaeology Research Centre of McMaster University (Dr. A. Cannon), funded by the Canadian Foundation for Innovation. Stable isotope analyses were performed at the University of Waterloo Environmental Isotope Lab. Additional trace element data, and a limited set of analyses of $\delta^{18} \mathrm{O}$, are available at: www.int-res.com/articles/suppl/b010p085_supp.pdf

\section{LITERATURE CITED}

Achterberg EP, Herzl VM, Braungardt CP, Millward GE (2003) Metal behaviour in an estuary polluted by acid mine drainage: the role of particulate matter. Environ Pollut 121:283-292

Amos CL (1977) The effect of tidal power structures on sediment transport and loading in the Bay of Fundy-Gulf of Maine system. In: Daborn G (ed) Fundy tidal power and the environment. Acadia University Press, Wolfville, NS, p 233-253

Arnold WS, Bert TM, Quitmeyer IR, Jones DS (1998) Contemporaneous deposition of annual growth bands in Mercenaria mercenaria (Linnaeus), Mercenaria campechiensis (Gmelin), and their natural hybrid forms. J Exp Mar Biol Ecol 223:93-109

Aubert H, Pinta M (1977) Trace elements in soils. O.R.S.T.O.M. (Agency: France) Elsevier
Bøggild OB (1930) The shell structure of the molluscs. K DanVidensk Selsk Skr Naturv Math Afd 2:231-326

Bourgoin BP (1990) Mytilus edulis shell as a bioindicator of lead pollution: considerations on bioavailability and variability. Mar Ecol Prog Ser 61:253-262

Brown GS, Kitchener AE, McGlasson WB, Barnes S (1996) The effects of copper and calcium foliar sprays on cherry and apple fruit quality. Sci Hortic 67:219-227

Carpenter WB (1844) On the microscopic structure of shells. Br Assoc Adv Sci Rep 1844:1-24

> Carroll M, Romanek CS (2008) Shell layer variation in trace element concentration for the freshwater bivalve Elliptio complanata. Geo-Mar Lett 28:369-381

Carter JG (1980) Environmental and biological controls of bivalve shell mineralogy and microstructure. In: Rhoads DC, Lutz RA (eds) Skeletal growth of aquatic organisms: biological records of environmental change. Plenum Press, New York, p 69-113

Dalai TK, Krishnaswami S, Sarin MM (2002) Barium in the Yamuna River System in the Himalaya: sources, fluxes, and its behavior during weathering and transport. Geochem Geophys Geosyst 3:1076

$>$ De Gregori I, Fuentes E, Rojas M, Pinochet H, Potin-Gautier M (2003) Monitoring of copper, arsenic and antimony levels in agricultural soils impacted and non-impacted by mining activities, from three regions in Chile. J Environ Monit 5:287-295

Di Marzio W, McInnes R (2005) Mission report: Carlos Anwandter Sanctuary (Rio Cruces), Chile. Comisión Nacional del Medio Ambiente (CONAMA) of Chile, Santiago

Dunca E, Schöne BR, Mutvei H (2005) Freshwater bivalves tell of past climates: But how clearly do shells from polluted rivers speak? Palaeogeogr Palaeoclimatol Palaeoecol 228:43-57

- Durrant SF, Ward NI (2005) Recent biological and environmental applications of laser ablation inductively coupled plasma mass spectrometry (LA-ICP-MS). J Anal At Spectrom 20:821-829

Harding L, Pretorius J, McGurk M (2007) Recent changes in the Rio Cruces: Comment on Mulsow \& Grandjean (2006). Ethics Sci Environ Polit 2007:1-3

Kennedy WJ, Taylor JD, Hall A (1969) Environmental and biological controls on bivalve shell mineralogy. Biol Rev Camb Philos Soc 44:499-530

> Kytömaa A, Nieminen S, Thuneberg P, Haapala H, Nuorteva $P$ (1995) Accumulation of aluminum in Hypogymnia physodes in the surroundings of a Finnish sulphitecellulose factory. Water Air Soil Pollut 81:401-409

> Lazareth CE, Vander Putten E, André L, Dehairs F (2003) High-resolution trace element profiles in shells of the mangrove bivalve Isognomon ephippium: a record of spatiotemporal variations? Estuar Coast Shelf Sci 57:1103-1114

Longerich HP, Jackson SE, Gunther D (1996) Laser ablation ICP-MS spectrometric transient signal data acquisition and analyte concentration calculation. J Anal At Spectrom 11:899-904

Lucassen EC, Smolders AJ, Roelofs JG (2002) Potential sensitivity of mires to drought, acidification and mobilisation of heavy metals: the sediment $\mathrm{S} /(\mathrm{Ca}+\mathrm{Mg})$ ratio as diagnostic tool. Environ Pollut 120:635-646

Manzano M, Ayora C, Domenech C, Navarette P, Garralona A, Turrero MJ (1999) The impact of the Aznalcóllar mine tailing spill on groundwater. Sci Total Environ 242:189-209

> McCulloch M, Fallon S, Wyndham T, Hendy E, Lough J, Barnes D (2003) Coral record of increased sediment flux to the inner Great Barrier Reef since European settlement. Nature 421:727-730 
Mulsow S, Grandjean M (2006) Incompatibility of sulphate compounds and soluble bicarbonate salts in the Rio Cruces waters: an answer to the disappearance of Egeria densa and black-necked swans in a RAMSAR sanctuary. Ethics Sci Environ Polit 2006:5-11

Mulsow S, Piovano E, Cordoba F (2009) Recent aquatic ecosystem response to environmental events revealed from ${ }^{210} \mathrm{~Pb}$ sediment profiles. Mar Pollut Bull 59:175-181

Murphy B, Morrison RD (2007) Introduction to environmental forensics. Academic Press, Burlington, MA

Negus C (1966) A quantitative study of growth and production of unionid mussels. I. The River Thames at Reading. J Anim Ecol 35:513-532

Neves RJ, Moyer SN (1988) Evaluation of techniques for age determination of freshwater mussels (Unionidae). Am Malacol Bull 6:179-188

Parada E, Peredo S, Lara G, Valdebenito I (1989) Growth, age and life span of the freshwater mussel Diplodon chilensis chilensis Gray, 1828. Arch Hydrobiol 115:563-573

Pearce NJ, Mann VL (2006) Trace metal variations in the shells of Ensis siliqua record pollution and environmental conditions in the sea to the west of mainland Britain. Mar Pollut Bull 52:739-755

Peltier GL, Meyer JL, Jagoe CH, Hopkins WA (2008) Using trace element concentrations in Corbicula fluminea to identify potential sources of contamination in an urban river. Environ Pollut 154:283-290

Perceval O, Coutillard Y, Pinel-Alloul B, Bonneris E, Campbell PG (2006) Long-term trends in accumulated metals $(\mathrm{Cd}, \mathrm{Cu}$ and $\mathrm{Zn})$ and metallothionein in bivalves from lakes within a smelter-impacted region. Sci Total Environ 369:403-418

Peredo S, Parada E, Valdebenito I, Peredo M (2005) Relocation of the freshwater mussel Diplodon chilensis (Hyriidae) as a strategy for its conservation and management. J Molluscan Stud 71:195-198

Pershagen G (1981) The carcinogenicity of arsenic. Environ Health Perspect 40:93-100

> Plafker G, Savage JC (1970) Mechanism of the Chilean earthquakes of May 21 and 22, 1960. Geol Soc Am Bull 81: 1001-1030

Prenant M (1927) Les formes minéralogiques du calcaire chez les êtres vivants, et le problème de leur déterminisme. Biol Rev Camb Philos Soc 2:365-393

Pye K, Croft DJ (2004) Forensic geosciences: principles, techniques and applications. Geol Soc London, Bath

Ravera O (2001) Monitoring of the aquatic environment by species accumulator of pollutants: a review. J Limnol 60(Suppl):63-78

Reinhardt EG, Nairn RB, López G (2010) Recovery estimates for the Rio Cruces after the May 1960 Chilean earthquake. Mar Geol 269:18-33

Risk MJ, Yeo RK (1980) Animal-sediment relationships in the

Editorial responsibility: Matthias Seaman,

Oldendorf/Luhe, Germany
Minas Basin, Bay of Fundy. In: McCann SB (ed) The coastline of Canada. Geological Survey of Canada Paper 80-10, p 189-194, Ottawa

> Rubio B, Nombela MA, Vilas F (2000) Geochemistry of major and trace elements in sediments of the Ria de Vigo (NW Spain): an assessment of metal pollution. Mar Pollut Bull 40:968-980

Saavedra Y, González A, Fernández P, Blanco J (2004) Interspecific variation of metal concentrations in three bivalve mollusks from Galicia. Arch Environ Contam Toxicol 47:341-351

Sherrell RM, Ross JM (1999) Temporal variability of trace metals in New Jersey pinelands streams: relationships to discharge and pH. Geochim Cosmochim Acta 63:3321-3336

Sinclair DJ, McCulloch MT (2004) Corals record low mobile barium concentrations in the Burdekin River during the 1974 flood: evidence for limited Ba supply to rivers? Palaeogeogr Palaeoclimatol Palaeoecol 214:155-174

Slater GG (2003) Stable isotope forensics: when isotopes work. Environ Forensics 4:13-23

Soldati AL, Jacob DE, Schone BR, Bianchi MM, Hajduk A (2009) Seasonal periodicity of growth and composition in valves of Diplodon chilensis patagonicus (d'Orbigny, 1835). J Molluscan Stud 75:75-85

Soto-Gamboa M, Lagos N, Quiroz E, Jaramillo E, Nespol R, Casanova-Katny A (2007) Causes of the disappearance of the aquatic plant Egeria densa and black-necked swans in a Ramsar sanctuary: comment on Mulsow \& Grandjean (2006). Ethics Sci Environ Polit 2007:7-10

Stumm W, Morgan JJ (1981) Aquatic chemistry, 2nd edn. Wiley, New York

Torre JA, Masso C (1975) Mercury content in molluscs in Pontevedra Ria as a measure of its degree of contamination by the metal. Bol Inst Esp Oceanogr 191:1-16

Turk TR, Risk MJ, Hirtle RW, Yeo RK (1980) Sedimentological and biological changes in the Windsor mudflat, an area of induced siltation. Can J Fish Aquat Sci 37:1387-1397

UAC (Universidad Austral de Chile) (2005) Segundo informe sobre 'Estudio sobre origen de mortalidades y disminucion de aves acuaticas en el santuario de la naturaleza Carlos Anwandter, en la Provincia de Valdivia'. UAC, Valdivia

Valdovinosa C, Pederossa P (2007) Geographic variations in shell growth rates of the mussel Diplodon chilensis from temperate lakes of Chile: implications for biodiversity conservation. Limnologica 37:63-75

- Veinott GI, Cornett RL (1996) Identification of annually produced opaque bands in the shell of the freshwater mussel Ellipito complanata using the seasonality of $\delta^{18} \mathrm{O}$. Can J Fish Aquat Sci 53:372-379

WWF (World Wildlife Fund) (2005) Findings and recommendation report. Assessment mission for the Carlos Anwandter Nature Sanctuary and CELCO Pulp Mill controversy in Valdivia, Chile. WWF International, Valdivia

Submitted: April 9, 2009; Accepted: June 9, 2010

Proofs received from author(s): July 20, 2010 